\title{
LATE PEST CONTROL IN DETERMINATE TOMATO CULTIVARS
}

\author{
Arlindo Leal Boiça Júnior; Marcos Aurélio Anequini Macedo²; Adalci Leite Torres²; Marina \\ Robles Angelini² \\ ${ }^{1}$ UNESP/FCAV - Depto. de Fitossanidade - Via de Acesso Prof. Paulo Donato Castellane - km 5 - 14884-900 - \\ Jaboticabal, SP-Brasil. \\ ${ }^{2}$ UNESP/FCAV - Programa de Pós-Graduação em Agronomia/Entomologia Agrícola. \\ *Corresponding author <aboicajr@fcav.unesp.br>
}

\begin{abstract}
The usage of insecticidal plants and others insect resistant varieties can be strong allies to the Integrated Pest Management (IPM), being able to reduce the number of insecticides applications and to minimize its effect to the man and the environment.The following control techniques were compared in field conditions, investigating the late pest control of two determinate tomato cultivars: a) Conventional - sprayings of metamidophos, buprofezin, acephate, cipermetrin, abamectin, permetrin, teflubenzuron and lufenuron, applied every three to six days; b) IPM - action threshold of each pest to the spraying of imidacloprid, triflumuron, lufenuron and abamectin; c) IPM - Azadirachta indica (neem) - Action threshold of each pest to the spraying of the nim oil (1.2\% of azadirachtin) at a concentration of $0.5 \%$. The IPM and IPM - Neem control techniques were efficient controlling the late pest of the tomato cultivar, not differing from the conventional treatment that presented the lowest levels of infestation. The conventional control technique, IPM and IPM-neem promoted bigger tomato production with increasements of up to $74 \%$. The number of sprayings was reduced up to $77 \%$ with the IPM and IPM - neem techniques, when compared to the conventional method. The neem product may be a promising alternative to the late pest control in the tomato field that adjusts to the IPM.

Key words: Azadirachta indica, Lycopersicon esculentum, chemical control, integrated pest management
\end{abstract}

\section{CONTROLE DE PRAGAS TARDIAS EM CULTIVARES DE TOMATEIRO DE CRESCIMENTO DETERMINADO}

\begin{abstract}
RESUMO: O uso de plantas inseticidas e de variedades pode ser forte aliado ao Manejo Integrado de Pragas (MIP), podendo reduzir o número de aplicações de inseticidas e minimizar seus efeitos ao homem e ao meio ambiente. Em condições de campo, visando o controle de pragas tardias do tomateiro em duas cultivares de crescimento determinado, compararam-se as seguintes táticas de controle: a) Convencional - pulverizações com os produtos metamidofós, buprofezin, acefato, cipermetrina, abamectina, permetrina, teflubenzuron e lufenuron, aplicados em intervalos de três a seis dias; b) MIP - nível de ação de cada praga para aplicações de imidacloprid, triflumuron, lufenuron e abamectina; c) MIP - Azadirachta indica (nim) - nível de ação de cada praga para aplicações de óleo de nim (1,2\% de azadiractina) a 0,5\%. As táticas de controle MIP e MIP - nim foram eficientes no controle das pragas tardias do tomateiro, quando a pressão da população é baixa, não diferindo do tratamento convencional que apresentou as menores médias de infestação. As táticas de controle convencional, MIP e MIPnim promoveram maiores produções do tomateiro, com incrementos de até $74 \%$. O número de pulverizações foi reduzido em até $77 \%$ com as táticas MIP e MIP - nim, comparado ao método convencional. O produto nim pode ser alternativa promissora no controle de pragas tardias do tomateiro em campo, que se ajusta ao MIP.

Palavras-chave: Azadirachta indica, Lycopersicon esculentum, controle químico, manejo integrado de pragas
\end{abstract}

\section{INTRODUCTION}

In the tomato culture it is common to perform systematic application of phytosanitary products based on calendar spraying, taking into account only the re- sidual activity of the products, without monitoring occurrence of pests or any level of damage to the culture. According to Gravena (1984), the late season pest control, which is dominated by lepidopteran borers and leafminers, through intensive sprayings with primarily 
chemical insecticides, having three day intervals between applications during the entire circle. Several times mixtures of two or more kinds of insecticides.

The indiscriminant use of these calendar applications may lead to serious problems including development of resistance to insecticides, pests resurgence and depletion of natural enemies, pollinating insects and sylvester animals, not to mention the unnecessary exposure of the farmer during the application, and higher potential pesticide residue to produce other impacts over the environment (Villas Bôas \& Castelo Branco, 1990; Gravena, 1991; Haji, 1992).

In the determinate tomato culture, late season pests such as the small borer, Neoleucinodes elegantalis (Guenee), the big borer, Helicoverpa zea (Boddie), and the tomato leafminer, Tuta absoluta (Meyrick) have contributed to the frequent use of broad spectrum insecticides. This has been pushing the scientific community to develop Integrated Pest Management (IPM). The isolated control techniques with phytosanitary products have not proven themselves effective, making it necessary to search for other strategies that make leading to sustainable results, and to monitor the pest insect populations (Gravena, 1984; Malta, 1999).

The use of insecticide plants and insect resistant varieties may be strong IPM allies, and making it possible to reduce the number of insecticides applications and minimizing its effects over men and environment. With these ideas in mind, the purpose of this work was to compare the late pest season control in two tomato varieties.

\section{MATERIAL AND METHODS}

The experiment was conducted on May 2001, under field conditions in Pongaí, State of São Paulo, Brazil, (49 $22^{\prime}$ W, $21^{\circ} 44^{\prime}$ S, 430 m altitude), during the "dry" season (Embrapa, 1999).

Tomato seedlings of determinate growth of the cultivars AP533 and Rio Grande, with six definite leaves each, obtained from nursery located in Zacarias, State of São Paulo, Brazil, were used. There the seeds were sowed on a commercial substrate in 288-cell polystyrene trays, one seed per cell, and kept in a high tunnel greenhouse protected on the sides by a $50 \%$ shade screen covered with 100 -micrometer polyethylene film to avoid pest infestation.

The soil was conventionally prepared through heavy disking, followed by one plowing and two light diskings. Correction of soil acidity was performed with one application of dolomitic lime (80\% Effective Neutralizing Power, ENP) 60 days before planting to reach $70 \%$ of base saturation. Fertilizers containing $60 \%$ of the NPK, as recommended by soil analysis, were ap- plied made before transplanting seedlings. Each replication was formed by ten furrows with $6 \mathrm{~m}$ length spaced by $1.3 \mathrm{~m}$, containing three plants per linear meter, totalizing 180 plants per plot. For each replication, it was used $52 \mathrm{~m}^{2}$ useful plot, totalizing 120 plants per plot. The remaining $40 \%$ of the fertilization was performed 20 days after the transplanting incorporated to the side of cultivation rows. Three further applications of NK were incorporated 40, 55 and 70 days after transplanting.

Cultural practices were carried out as recommended for the tomato crops (Embrapa, 1994). Four treatments were used: 1) no pest controls; 2) conventional pest control, a calendar schedule used by farmers; 3) Integrated Pest Management (IPM); 4) IPMneem.

Control treatment consisted of two cultivars with no insecticide use and natural product. For conventional treatment the methods used by the farmer were adopted. In that treatment, insecticides applications are performed guided by a pre-established calendar every three to six days. For the IPM treatment, insecticides applications were performed as recommended by "Centro de Manejo Integrado de Pragas (CEMIP)" (Center of Integrated Pest Management), adopting the action threshold (Table 1) for decision making. As for IPM-neem, the methods used were the same as the IPM, only the insecticides were replaced by the natural product Neem (Table 2).

For tomato leafminer control decision during fruiting phase, we had samples of four fruit clusters per plant in 20 random plants per plot, and we applied controls when $5 \%$ of the tomato fruit clusters were infested. As for the borers, it has been visually observed that two tomato fruit clusters in 20 plants per plot, for a total of 200 fruits, we used average of $1 \%$ of these fruits infested as the action threshold. Evaluations were conducted every seven days, and when the control threshold was achieved, even if by a single plot, pesticide applications were made in every plot.

Table 1 - Action threshold used regarding decision making in the Integrated Pest Management (IPM), for monitored late pests of tomato cultivars of determinate growth. Pongai, São Paulo, Brazil, 2001.

\begin{tabular}{lcc}
\hline & Late pests & Action threshold \\
\hline Borers & $\begin{array}{c}\text { Helicoverpa zea } \\
\text { Neoleucinodes } \\
\text { elegantalis }\end{array}$ & $1 \%$ of bored fruits \\
\hline Leafminer & Tuta absoluta & $\begin{array}{c}5 \% \text { of stem with } \\
\text { infested fruit }\end{array}$ \\
\hline
\end{tabular}

Source: Gravena (1984) 
Table 2 - Synthetic insecticides and neem-based product used for pest control in tomato cultivars of determinate growth. Pongai, SP, Brazil, 2001.

\begin{tabular}{|c|c|}
\hline Technical name & Dose (commercial product) \\
\hline methamidophos $\mathrm{BR}^{1}$ & $100 \mathrm{~mL} 100 \mathrm{~L}^{-1}$ water \\
\hline cipermetrin $200 \mathrm{CE}^{1}$ & $30 \mathrm{~mL} 100 \mathrm{~L}^{-1}$ water \\
\hline abamectin $18 \mathrm{CE}^{1,2}$ & $100 \mathrm{~mL} 100 \mathrm{~L}^{-1}$ water \\
\hline permethrin $500 \mathrm{CE}^{1}$ & $20 \mathrm{~mL} 100 \mathrm{~L}^{-1}$ water \\
\hline permethrin $384 \mathrm{CE}^{1}$ & $26 \mathrm{~mL} 100 \mathrm{~L}^{-1}$ water \\
\hline teflubenzuron $150^{1}$ & $25 \mathrm{~mL} 100 \mathrm{~L}^{-1}$ water \\
\hline triflumuron $250 \mathrm{PM}^{1,2}$ & $60{\mathrm{~g} 100 \mathrm{~L}^{-1}}^{-1}$ \\
\hline lufenuron $\mathrm{CE}^{1,2}$ & $80 \mathrm{~mL} 100 \mathrm{~L}^{-1}$ water \\
\hline imidacloprid $^{2}$ & $200 \mathrm{~g} \mathrm{ha}^{-1}$ \\
\hline azadirachtin $^{3}$ & $500 \mathrm{~mL} 100 \mathrm{~L}^{-1}$ water \\
\hline
\end{tabular}

${ }^{1}$ Synthetic insecticides used in the conventional treatment. ${ }^{2}$ Synthetic insecticides used in the IPM. ${ }^{3}$ Natural product (oil) used in the IPM-neem (1.2\% azadirachtin).

A production estimate was determinate after three harvests, being that the first to were destined to in natura, and the third to industry, and notes regarding the weight of the fruits of every plot were taken.

The obtained data were submitted to the ANOVA by the $\mathrm{F}$ test, and means were compared through Tukey test $(P \leq 0.05)$.

\section{RESULTS AND DISCUSSION}

The IPM and IPM-neem control techniques were as effective as the conventional technique when controlling the three late season pests in a tomato cultivar of determinate growth (Table 3). Fifty-four days after transplanting, the big borer $(H$. zea) predominated, and it exceeded the action threshold, necessitating control at this time for borers and leafminers (Figure 1e-f-g-h). Such fact could be related to the nearby corn culture, which, at this point in time was sprouting, in view of the fact that the big borer is a secondary pest when it comes to tomato culture. The mean percentage of the fruits damaged by $H$. zea was inversely related to the tomato production $\left(r=-0.64^{* *}\right)$, which means, while the number of damaged fruits increased, the production decreased (Figure 2).

In general, among the late season pests, the leafminer was responsible for the higher number of sprayings (Figures 1e-f-g-h), affecting tomato production, as seen in the negative and highly significant correlation between the mean percentage of fruits dam-
Table 3 - Mean percentage of tomato clusters damaged by Tuta absoluta, and number of fruits damaged by Neoleucinodes elegantalis and Helicoverpa zea in two tomato cultivars of determinate growth subjected to three control techniques. Pongai, São Paulo, Brazil, 2001.

\begin{tabular}{|c|c|c|c|}
\hline \multirow[b]{2}{*}{ Cultivar (C) } & T. absoluta & \multirow[b]{2}{*}{ N. elegantalis } & \multirow[b]{2}{*}{ H. zеа } \\
\hline & $\begin{array}{c}\text { Reprodutive } \\
\text { phase }\end{array}$ & & \\
\hline AP533 & $1.82 \mathrm{a}$ & 0.37 a & $0.33 \mathrm{a}$ \\
\hline Rio Grande & $1.72 \mathrm{a}$ & 0.45 a & $0.35 \mathrm{a}$ \\
\hline F Test & $0.14^{\mathrm{ns}}$ & $0.97^{\mathrm{ns}}$ & $0.26^{\mathrm{ns}}$ \\
\hline \multicolumn{4}{|l|}{ Treatment (T) } \\
\hline Control & $5.45 \mathrm{a}$ & $1.17 \mathrm{a}$ & $0.74 \mathrm{a}$ \\
\hline Conventional & $0.03 \mathrm{~b}$ & $0.08 \mathrm{~b}$ & $0.07 \mathrm{c}$ \\
\hline IPM & $0.73 \mathrm{~b}$ & $0.17 \mathrm{~b}$ & $0.26 \mathrm{~b}$ \\
\hline IPM-Nim & $0.87 \mathrm{~b}$ & $0.23 \mathrm{~b}$ & $0.29 \mathrm{~b}$ \\
\hline F Test & $76.45^{* *}$ & $43.66 * *$ & $37.62 * *$ \\
\hline $\mathrm{F}(\mathrm{C} \times \mathrm{T})$ & $0.66^{\mathrm{ns}}$ & $0.57^{\mathrm{ns}}$ & $1.94^{\mathrm{ns}}$ \\
\hline C.V. (\%) & 45.30 & 53.09 & 38.07 \\
\hline
\end{tabular}

Means followed by the same lower-case letter in the column are not different by Tukey test $\left(* * 1 \%\right.$, F test, ${ }^{n}$ not significant).

aged by the leafminer and the production $(\mathrm{r}=-0.53 * *)$ in Figure 2. The small borer population initiated in the end of March (Figures 1a-b), and exceeded the action threshold quickly in the first ten days of April (Figure $1 \mathrm{~h}$ ), being that its levels were given together with the leafminer (Figures 1e-g-h).

The conventional control technique maintained the lowest population of late season pests, the leafminer being the most affected one, due to the short time between the insecticides applications, levels of the small borer, were higher in the conventional plots and caused small strings to the fruit by harvest (Figures 1c-d). That confirms the report provided by França (1984), Reis et al. (1989), Gravena (1991) and Reis \& Souza (1996), which said that the small borer is hard to control, specially at high population pressure, because its equilibrium level is always close to the action threshold level, therefore, requiring constant chemical control.

Rodrigues Filho et al. (1998) interviewed tomato farmers and reported that the $N$. elegantalis control is maintained through preventative chemical applications. These farmers start the small borer control from the initiation of fruit set and maintain a regime of three spray per week, in an average, under low technical quality and questionable efficiency. Therefore, França (1984) suggests that the control threshold is placed a little above the equilibrium position, or that the control should proceed at the initial signs of injury in order to prevent any loss. Malta (1999) determined 


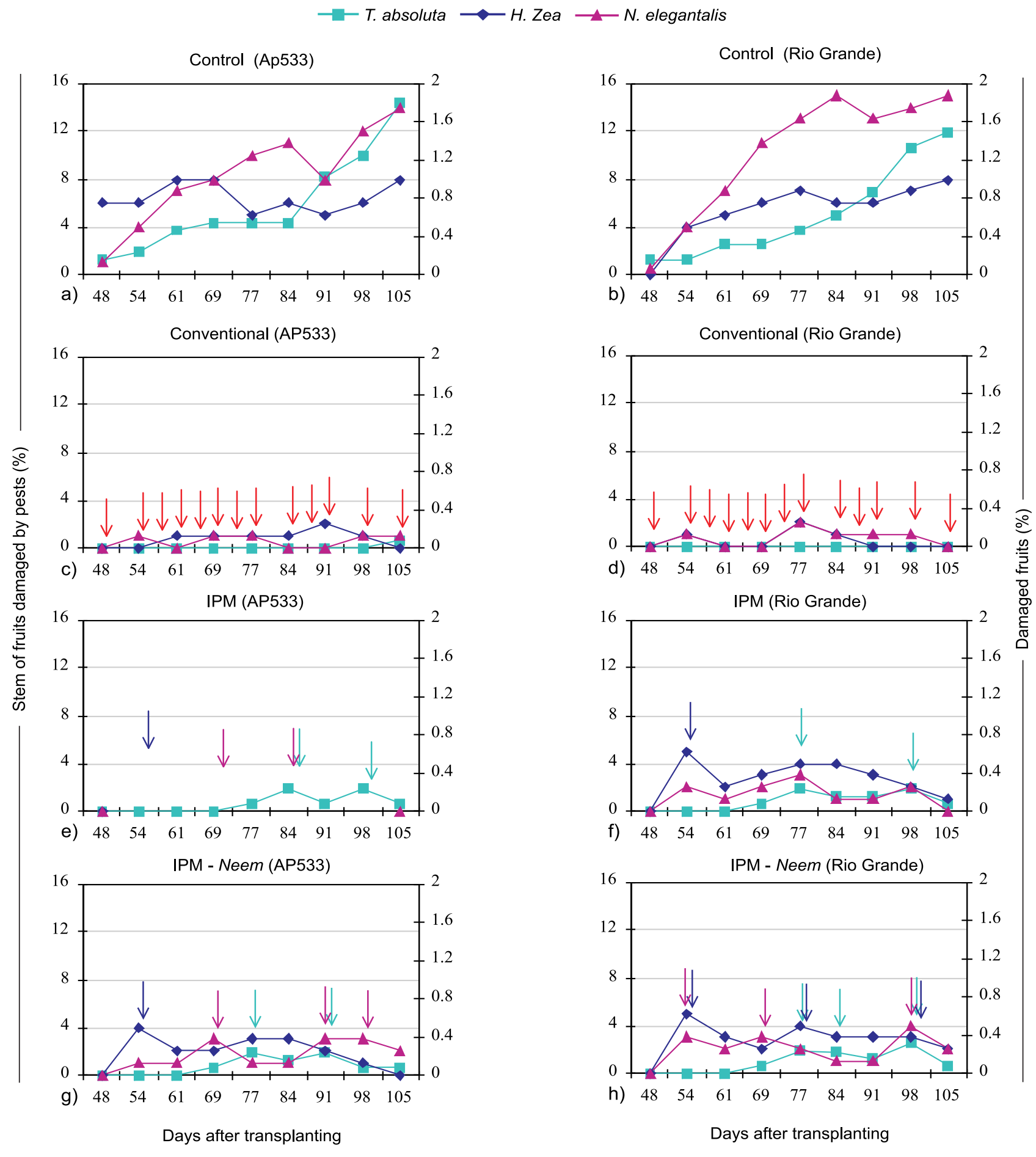

Figure 1 - Percentage of tomato clusters damaged by Tuta absoluta, Helicoverpa zea, and Neoleucinodes elegantalis, in two tomato cultivars of determinate growth, subjected to three control techniques. Pongai, São Paulo, Brazil, 2001. * Arrow indicated spray application necessitate by an action threshold of exceeded by pest.

the action threshold of 3\% of borer entrance signs, instead of $5 \%$.

With the development of the plants, the population differences between the treatments IPM and IPM-Nim and the traditional have the tendency to get closer related (Figure 1c-d-e-f-g-h), agreeing with Jordão \& Nakano (2000).
All late pest control techniques potentialized the tomato yield when compared to control (Table 4). There was no difference between the cultivars in terms of percentage of fruit injured; there was, however, difference between the control techniques. But there was a larger amount of fruits from the AP533 cultivar destined to the industry when compared to 

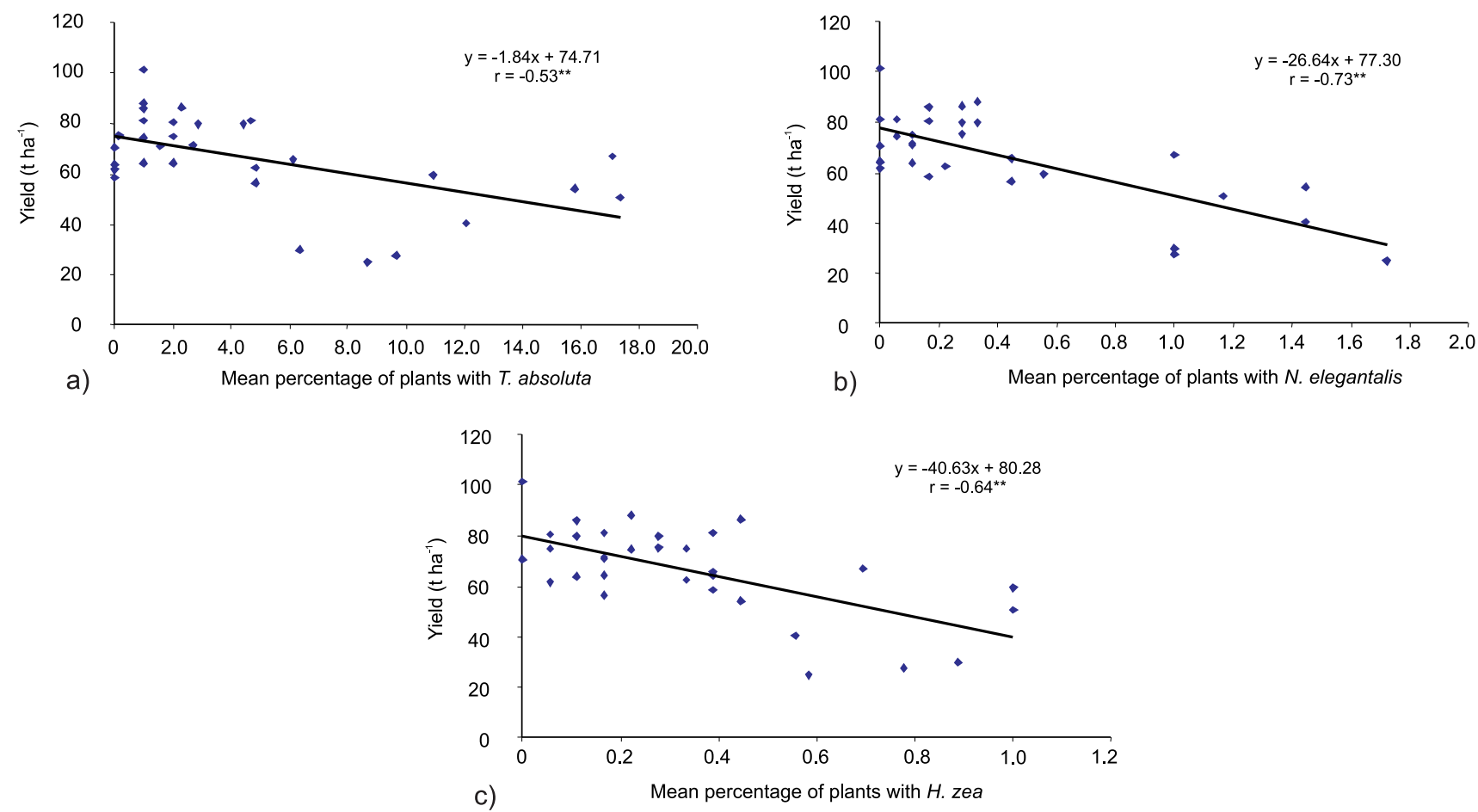

Figure 2 - Linear regression and correlation (r) between the mean percentage of plants with Tuta absoluta live larvae (a) and the average number of fruits damaged by Neoleucinodes elegantalis (b) and by Helicoverpa zea (c) and the production of tomato of determinate growth.

Table 4 - Mean percentage of fruit lost because of borers and production for in natura market and industry, considering two tomato cultivars of determinate growth, subjected using the three control techniques. Pongai, São Paulo, Brazil, 2001.

\begin{tabular}{|c|c|c|c|c|}
\hline \multirow{2}{*}{ Cultivar (C) } & \multirow{2}{*}{ Fruits with borers } & \multicolumn{3}{|c|}{ Production } \\
\hline & & in natura Market & Industry & Total \\
\hline & $\%$ & - & t ha ${ }^{-1}-\ldots$ & - \\
\hline AP533 & 8.61 a & 52.88 a & 14.97 a & 67.85 a \\
\hline Rio Grande & $5.67 \mathrm{~b}$ & $57.03 \mathrm{a}$ & $7.89 \mathrm{~b}$ & 64.92 a \\
\hline F Test & $4.70 *$ & $0.84^{\text {ns }}$ & $30.89 * *$ & $0.45^{\text {ns }}$ \\
\hline \multicolumn{5}{|l|}{ Treatment (T) } \\
\hline Control & $12.97 \mathrm{a}$ & $31.03 \mathrm{~b}$ & $13.01 \mathrm{a}$ & $44.04 \mathrm{~b}$ \\
\hline Conventional & $4.76 \mathrm{~b}$ & 65.82 a & 10.87 a & 76.69 a \\
\hline IPM & $5.93 \mathrm{~b}$ & $62.65 \mathrm{a}$ & 10.91 a & 73.56 a \\
\hline IPM-Neem & $4.90 \mathrm{~b}$ & $60.41 \mathrm{a}$ & 10.92 a & 71.33 a \\
\hline F Test & $8.39 * *$ & $12.76 * *$ & $0.68^{\mathrm{ns}}$ & $10.62 * *$ \\
\hline $\mathrm{F}(\mathrm{C} \times \mathrm{T})$ & $0.29^{\text {ns }}$ & $0.17^{\mathrm{ns}}$ & $0.10^{\mathrm{ns}}$ & $0.18^{\text {ns }}$ \\
\hline C.V. (\%) & 53.62 & 23.19 & 31.52 & 19.75 \\
\hline
\end{tabular}

Means followed by the same lower-case letter in the column are not different by Tukey test (** $1 \%$ and * $5 \% \mathrm{~F}$ test, ns - not significant).

the Rio Grande cultivar. There was no difference between the control techniques and the control treatment (Table 4). Such fact is a consequence of the damage caused by borers and leafminers on AP533, which was more significant than the harm caused on Rio Grande. Fruits with borers are not culled when sent to the industry market, which explains the difference of production with this purpose.

The conventional control technique was responsible for the highest increase in tomato yield $74.14 \%$, not different from IPM (67.03\%) or IPMNeem (61.97\%). Ahmed (2000) observed, in field conditions, the increasement of $74 \%$ in the tomato pro- 
duction with the application of watery neem seed extract, and of $46 \%$ with two incorporations of neem seeds $(2 \mathrm{~g})$ to the soil. As for the NeemAzal commercial product $\left(5 \mathrm{~mL} \mathrm{~L}^{-1}\right)$ it increased the production in $38 \%$ and the insecticide fenvalerate in $28 \%$. In okra, that same author observed an increase of up to $162 \%$ in the first year of planting and of $52 \%$ in the following year, with the application of neem seed water extracts $\left(50 \mathrm{~g} \mathrm{~L}^{-1}\right)$.

The number of sprayings for late pests following the farmer's calendar (Conventional) was 13, being reduced in up to $77 \%$ to IPM technique and $62 \%$ to IPM-neem (Table 5). Gravena et al. (1998) reported that reducing in up to $70 \%$ the number of insecticide spraying is possible, using pest monitoring and action threshold and associate choice of insecticides, which was confirmed by the current research in the IPM and IPM-Neem techniques, which presented differences from one another of one spraying to AP533 cultivar and two to Rio Grande cultivar.

The influence of the small borer over the tomato production is evident in the highly significant negative correlation between the mean percentage of fruits damaged by $N$. elegantalis and production $\left(\mathrm{r}=-0.73^{* *}\right)$ in Figure 2, being that as the fruits with $N$. elegantalis increased, the production decreased.

In addition to reduce the number of sprayings, the IPM-neem control technique presented more vigorous plants than those presented by the conventional and IPM control. Such fact has also been noted by Ahmed (2000) regarding tomato culture in field conditions. The authors observed yet, a strong effect in the growing index, in the plants' height and the number of leaves carried by each plant when treated with watery neem seed extract $\left(50 \mathrm{~g} \mathrm{~L}^{-1}\right)$ and the commercial product NeemAzal $\left(5 \mathrm{~mL} \mathrm{~L}^{-1}\right)$. The same was observed in the culture of okra.

The IPM and IPM-neem techniques showed best results when compared as the conventional technique in the late pests control in tomato cultivars of determinate growth. These techniques promoted larger tomato productions, with increasements of up to $74 \%$. The number of sprayings was reduced in up to $77 \%$ with the IPM and IPM-neem techniques, in relation to the conventional control.

In face of that, the natural product shown as promising alternative in the tomato field late pests control, which adjusts to the Integrated Pest Management program.

\section{REFERENCES}

AHMED, M.M.M. Studies on the control of insect pests in vegetables (okra, tomato, and onion) in Sudan with special reference to neem-preparations. Giessen: University of Giessen, Faculty of Agrarwissenschaften, Ökotrophlogie und Umweltmanagement, 2000. 122p. (Dissertation - Doctor).

EMPRESA BRASILEIRA DE PESQUISA AGROPECUÁRIA EMBRAPA. Recomendações técnicas para o cultivo do tomate industrial em condições irrigadas. Petrolina: EMBRAPA-CPATSA, 1994. 52p. (Circular Técnica, 30).

EMPRESA BRASILEIRA DE PESQUISA AGROPECUÁRIA EMBRAPA. Sistema brasileiro de classificação de solos. Brasília: Embrapa Solos, 1999. 412p.

FRANÇA, F.H. Considerações sobre um programa de manejo integrado de pragas de hortaliças no Brasil. In: CONGRESSO BRASILEIRO DE OLERICULTURA, 24., Jaboticabal, 1984. Anais. Jaboticabal: Sociedade de Olericultura do Brasil, 1984. p.104-128.

GRAVENA, S. Manejo integrado de pragas do tomateiro. In: CONGRESSO BRASILEIRO DE OLERICULTURA, 24. Jaboticabal, 1984. Anais. Jaboticabal: Sociedade de Olericultura do Brasil, 1984. p.129-149.

GRAVENA, S. Manejo integrado de pragas do tomateiro. In: ENCONTRO NACIONAL DE PRODUÇÃO E ABASTECIMENTO DE TOMATE, 2., Jaboticabal, 1991. Anais. Jaboticabal: FUNEP/SEB, 1991. p.105-159.

GRAVENA, S.; BENVENGA, S.; ABREU JUNIOR, H.; GROPPO, G.A.; ZANDER, R.; KLEIN-GUNNWIEK, R. Manejo ecológico de pragas e doenças do tomate envarado: redução das pulverizações por monitoramento. In: INTERNATIONAL CONFERENCE ON SUSTAINABLE AGRICULTURE IN TROPICAL AND SUBTROPICAL HIGHLANDS WITH SPECIAL REFERENCE TO LATIN AMERICA, Rio de Janeiro, 1998. Proceedings. Rio de Janeiro, 1998. p.105.

HAJI, F.N.P. Histórico e situação atual da traça-do-tomateiro nos perímetros irrigados do Submédio São Francisco, In: SIMPÓSIO DE CONTROLE BIOLÓGICO. EMOPI, 3., Campinas, 1992. Anais. Jaguariúna: EMBRAPA-CNPDA, 1992. p.57-58.

JORDÃO, A.L.; NAKANO, O. Controle de lagartas dos frutos do tomateiro pelo ensacamento das pencas. Anais da Sociedade Entomológica do Brasil, v.29, 773-782, 2000.

MALTA, A.W.O. Flutuação populacional e calibração de níveis de ação para o manejo integrado de pragas do tomateiro na mesoregião metropolitana de Belo Horizonte. Lavras: UFLA, 1999. 91p. Dissertação (Mestrado).

REIS, P.R.; SOUZA, J.C. Controle da broca pequena, Neoleucinodes elegantalis (Guéenne, 1854) (Lepidoptera; Pyralidae), com inseticidas fisiológicos, em tomateiro estaqueado. Anais da Sociedade Entomológica do Brasil, v.25, p.65-69, 1996.

REIS, P.C.; SOUZA, J.C.; MALTA, A.W.O. Eficiência de inseticidas para o controle da broca-pequena, Neoleucinodes elegantalis (Guéene, 1854) (Lepidoptera; Pyralidae), fruto do tomateiro, Lycopersicon esculentum Mill. Anais da Sociedade Entomológica do Brasil, v.18, p.131-144, 1989.

RODRIGUES FILHO, I.L.; MARCHIOR, L.C.; REIS, C.A.; GRAVENA, S.; MENEZES, E.B. Aspectos da tomaticultura do município de Paty do Alferes - RJ, balizados pela relação com Neoleucinodes elegantalis (Guéene, 1854) (Lepidoptera; Pyralidae). In: CONGRESSO BRASILEIRO DE ENTOMOLOGIA, 17. Rio de Janeiro, 1998. Resumos. Rio de Janeiro: Sociedade Entomológica do Brasil, 1998. p.306.

VILLAS BÔAS, G.L.; CASTELO BRANCO, M. Manejo integrado de pragas em hortaliças. In: FERNANDES, O.A.; CORREA, A.C.B.; BORTOLI, S. A. (Ed.) Manejo integrado de pragas. Jaboticabal: FUNEP, 1990. v.1, p.147-150.

Received March 28, 2006

Accepted August 28, 2007 